\title{
Spatial-temporal variations in riverine carbon strongly influenced by local hydrological events in an alpine catchment
}

\author{
Xin Wang ${ }^{1,2} \star$, Ting Liu ${ }^{1,}$, Liang Wang ${ }^{1}$, Zongguang Liu ${ }^{1,2}$, Erxiong Zhu ${ }^{1,2}$, Simin Wang ${ }^{1,2}$, Yue Cai ${ }^{1,2}$, \\ Shanshan Zhu ${ }^{1,2}$, and Xiaojuan Feng ${ }^{1,2}$ \\ ${ }^{1}$ State Key Laboratory of Vegetation and Environmental Change, Institute of Botany, \\ Chinese Academy of Sciences, Beijing, 100093, China \\ ${ }^{2}$ University of Chinese Academy of Sciences, Beijing, 100049, China \\ ฟ These authors contributed equally to this work.
}

Correspondence: Xiaojuan Feng (xfeng@ibcas.ac.cn)

Received: 17 December 2020 - Discussion started: 22 December 2020

Revised: 1 April 2021 - Accepted: 7 April 2021 - Published: 20 May 2021

\begin{abstract}
Headwater streams drain $>70 \%$ of global land areas but are poorly monitored compared with large rivers. The small size and low water buffering capacity of headwater streams may result in a high sensitivity to local hydrological alterations and different carbon transport patterns from large rivers. Furthermore, alpine headwater streams on the "Asian water tower", i.e., Qinghai-Tibetan Plateau, are heavily affected by thawing of frozen soils in spring as well as monsoonal precipitation in summer, which may present contrasting spatial-temporal variations in carbon transport compared to tropical and temperate streams and strongly influence the export of carbon locked in seasonally frozen soils. To illustrate the unique hydro-biogeochemistry of riverine carbon in Qinghai-Tibetan headwater streams, here we carry out a benchmark investigation on the riverine carbon transport in the Shaliu River (a small alpine river integrating headwater streams) based on annual flux monitoring, sampling at a high spatial resolution in two different seasons and hydrological event monitoring. We show that riverine carbon fluxes in the Shaliu River were dominated by dissolved inorganic carbon, peaking in the summer due to high discharge brought by the monsoon. Combining seasonal sampling along the river and monitoring of soil-river carbon transfer during spring thaw, we also show that both dissolved and particulate forms of riverine carbon increased downstream in the pre-monsoon season due to increasing contribution of organic matter derived from thawed soils along the river. By comparison, riverine carbon fluctuated in the summer, likely associated with sporadic inputs of organic matter supplied by local precipi-
\end{abstract}

tation events during the monsoon season. Furthermore, using lignin phenol analysis for both riverine organic matter and soils in the basin, we show that the higher acid-to-aldehyde $(\mathrm{Ad} / \mathrm{Al})$ ratios of riverine lignin in the monsoon season reflect a larger contribution of topsoil likely via increased surface runoff compared with the pre-monsoon season when soil leachate lignin $\mathrm{Ad} / \mathrm{Al}$ ratios were closer to those in the subsoil than topsoil solutions. Overall, these findings highlight the unique patterns and strong links of carbon transport in alpine headwater catchments with local hydrological events. Given the projected climate warming on the Qinghai-Tibetan Plateau, thawing of frozen soils and alterations of precipitation regimes may significantly influence the alpine headwater carbon transport, with critical effects on the biogeochemical cycles of the downstream rivers. The alpine headwater catchments may also be utilized as sentinels for climate-induced changes in the hydrological pathways and/or biogeochemistry of the small basin.

\section{Introduction}

Headwater streams, as the origins of the stream network, comprise nearly $90 \%$ of the total length of global river networks (Downing et al., 2012) and drain $>70 \%$ of global land areas (Gomi et al., 2002). They are hence important sources of water, sediment, organic matter and nutrients for downstream regions (Gomi et al., 2002) and critical for maintaining ecological functions of the entire fluvial system including 
biogeochemical cycling (Biggs et al., 2017). However, headwater streams remain under-investigated in terms of biogeochemical processes and carbon transport patterns compared with large rivers so far, constraining an accurate understanding of the "boundless carbon cycle" (Battin et al., 2008).

Headwater streams differ from large rivers in several aspects that may affect their carbon transport. First, headwater streams have narrower width and shallower depth than large rivers and are closely connected with adjacent terrestrial ecosystems via water and solute exchange (Battin et al., 2008; Öquist et al., 2014). Second, headwater streams have smaller drainage areas and buffering capacity for water flow than large rivers (Rivenbark and Jackson, 2004; Svec et al., 2005). In addition, water in headwater streams has a shorter residence time (Caillon and Schelker, 2020). The above characteristics collectively result in high sensitivity of headwater streams to local hydrological alterations or sporadic events such as precipitation (Benda et al., 2005; Richardson et al., 2005). Thus, riverine carbon transport in headwater streams may show a fast and strong response to local environmental variations and are receiving increasing attention (Gomi et al., 2002; Mann et al., 2015; Biggs et al., 2017) to improve our understanding of riverine carbon cycling (Flury and Ulseth, 2019; French et al., 2020; Battin et al., 2008).

Studies on headwater carbon transport have largely examined tropical and temperate streams in association with rainstorm events (Pereira et al., 2014; Argerich et al., 2016; Johnson et al., 2006). By comparison, headwater streams residing in alpine regions that are heavily affected by freezethaw and snow melting events are less well studied (Mann et al., 2015; Bröder et al., 2020; Chiasson-Poirier et al., 2020). The Qinghai-Tibetan Plateau, known as the "Asian water tower", harbors numerous headwater streams for seven major Asian rivers (Immerzeel et al., 2010; Qiu, 2008). This region is covered by large areas of glaciers, permafrost and seasonally frozen soils (not underlain by permafrost layers), which are strongly affected by thawing with increasing temperatures in the pre-monsoon spring. Thawing of frozen soils and deepening of active layers can strongly affect catchment hydrology, including creating vertical and lateral flows, increasing soil filtration, and enhancing groundwater-surface water exchange and baseflow (Song et al., 2019; Walvoord and Kurylyk, 2016). In addition, this region has a continental monsoon climate and is hence significantly affected by intense precipitation in the summer monsoon (Zou et al., 2017). Hydrological alterations induced by both spring thawing and summer monsoon likely result in unique seasonal patterns in riverine carbon transport in the Qinghai-Tibetan streams compared to headwater streams in other regions including the Arctic or tropical rivers (Zhang et al., 2013). The exported carbon could originate from both recently fixed modern carbon from terrestrial plants and aged carbon preserved in frozen soils within this region (Song et al., 2020; Qu et al., 2017), which show different decomposition characteristics (Mann et al., 2015) and thus may influence regional carbon cycling. However, the seasonal transport dynamics of these carbon pools along the Qinghai-Tibetan river continuum are relatively poorly investigated. In particular, as one of the most climate-sensitive regions, warming-induced alterations of permafrost zone and precipitation patterns may change the hydrogeological characteristics of headwater streams (Chang et al., 2018) and thus affect riverine carbon transport. Yet, the variations in riverine carbon and its response to thawing and precipitation events in headwater streams on the QinghaiTibetan Plateau are poorly resolved.

To illustrate the unique hydro-biogeochemistry of riverine carbon in alpine headwater streams on the Qinghai-Tibetan Plateau, riverine carbon transports were investigated in a small river (Shaliu River) feeding into the Qinghai Lake at three different levels. First, we provide a year-long biweekly monitoring record on the water discharge and concentrations of dissolved organic carbon (DOC) and dissolved inorganic carbon (DIC) to estimate monthly fluvial carbon fluxes for 1 year. Second, we use bulk concentration and biomarker (lignin phenols) analyses to examine riverine carbon composition and its variations along the Shaliu River by sampling at a high spatial resolution in both pre-monsoon (spring thawing) and monsoon seasons. Third, to further identify the influence of hydrological events on the spatial-temporal variations in riverine carbon, we examine carbon transport from the adjacent soils to the river during a $79 \mathrm{~d}$ thawing period and a short-term monsoon precipitation event. The characterization of lignin phenols, which are unique tracers of terrestrial-plant-derived organic matter (OM; Hedges and Mann, 1979) and provide useful information on the oxidation stage of terrestrial OM (indicated by lignin phenol acid-to-aldehyde ratios; Bianchi and Canuel, 2011; Hedges et al., 1988), allows us to investigate the sources and transport of terrestrial $\mathrm{OM}$ in rivers. Based on these investigations, we hypothesize that the release of carbon from frozen soils during thawing events leads to a downstream increase in riverine carbon in the pre-monsoon season while carbon inputs through surface runoff in short-term precipitation events may result in a fluctuation of riverine carbon. Collectively, these investigations provide a benchmark illustration of riverine carbon transport in headwater streams on the QinghaiTibetan Plateau.

\section{Materials and methods}

\subsection{Study area}

The Shaliu River, with a length of $110 \mathrm{~km}$ and a catchment area of $1442 \mathrm{~km}^{2}$ (Zhang et al., 2013) and a mean annual daily discharge of $7.5 \mathrm{~m}^{3} \mathrm{~s}^{-1}$ from 2015 to 2016 (from Gangcha hydrological station), is the second largest river flowing into the Qinghai Lake on the northeastern edge of the Qinghai-Tibetan Plateau at an altitude of 3200-3800 m above sea level (Fig. 1a). The Shaliu River is a small river in- 
tegrating headwater streams of orders of 1-3 on the QinghaiTibetan Plateau. It flows through a semiarid alpine region widely covered by seasonally frozen soils (Wang et al., 2018) and is relatively well protected from human activities (Zhang et al., 2013; Cheng et al., 2018). The Shaliu River basin is covered by grassland ( $\sim 71 \%$ ) dominated by Potentilla anserina Rosaceae, Elymus nutans Griseb and Deyeuxia arundinacea (Liu et al., 2018); bare land (16\%); and wetland (10\%; Cheng et al., 2018). The soils in the basin are mainly Gelic Cambisol (IUSS working group WRB, 2015) underlain by Triassic sandstone, late Cambrian metamorphic rocks (schist and gneiss), granites (Zhang et al., 2013) and a widespread distribution of late Paleozoic marine sedimentary rocks (Jin et al., 2009; Xiao et al., 2013), and the latter rocks contain abundant limestone rich in carbonates (Bissell and Chilingar, 1967). The Shaliu River basin is under a continental monsoon climate characterized by warm, humid summers and cold, dry winters (Wang et al., 2018). The mean annual temperature is $-0.5^{\circ} \mathrm{C}$ within the basin ( $\mathrm{Li}$ et al., 2013) and mean annual precipitation is $370 \mathrm{~mm}, \sim 90 \%$ of which occurs in the monsoon season (June to September; Fig. S1; Wu et al., 2016). The seasonally frozen soils in the watershed start to thaw in late April to early May (i.e., the onset of premonsoon season) and refreeze in late October. The river is partly or fully frozen from November to March.

\subsection{Sample collection}

For annual flux assessment, the daily discharge of the Shaliu River was obtained from Gangcha hydrological station (SLH-4) where river water was collected biweekly from the middle of the stream using pre-washed high-density polyethylene containers from May 2015 to April 2016. The high-density polyethylene containers were cleaned with soapy water, soaked in $10 \% \mathrm{HCl}$ solution for $24 \mathrm{~h}$, rinsed three times using Milli-Q water before drying, and rerinsed three times with field river water prior to sampling. An aliquot of the water was immediately filtered through $0.45 \mu \mathrm{m}$ acetate syringe filters and preserved with $0.02 \%$ saturated mercury chloride $\left(\mathrm{HgCl}_{2}\right)$ in vials without headspace in the dark for DIC analysis. The remaining water was filtered through pre-combusted $\left(550^{\circ} \mathrm{C}, 4 \mathrm{~h}\right)$ and pre-weighted $0.7 \mu \mathrm{m} \mathrm{GF} / \mathrm{F}$ filters, preserved with a few drops of saturated $\mathrm{HgCl}_{2}$, and kept frozen in acid-washed glass vials until DOC analysis.

For seasonal water sampling, river water was collected using the same method as above at five evenly distributed stations along the Shaliu River in May (pre-monsoon season) and August (monsoon season), 2015 (Fig. 1a; SLH-5 was only sampled in the pre-monsoon season). Water temperature, $\mathrm{pH}$, dissolved oxygen (DO) and conductivity were measured in situ using a multi-parameter device (ProfiLine Multi 3320, WTW, Germany). Water was filtered and preserved as above for DIC and DOC analyses. Moreover, filtered water $(0.7 \mu \mathrm{m})$ was kept frozen before measuring ni-
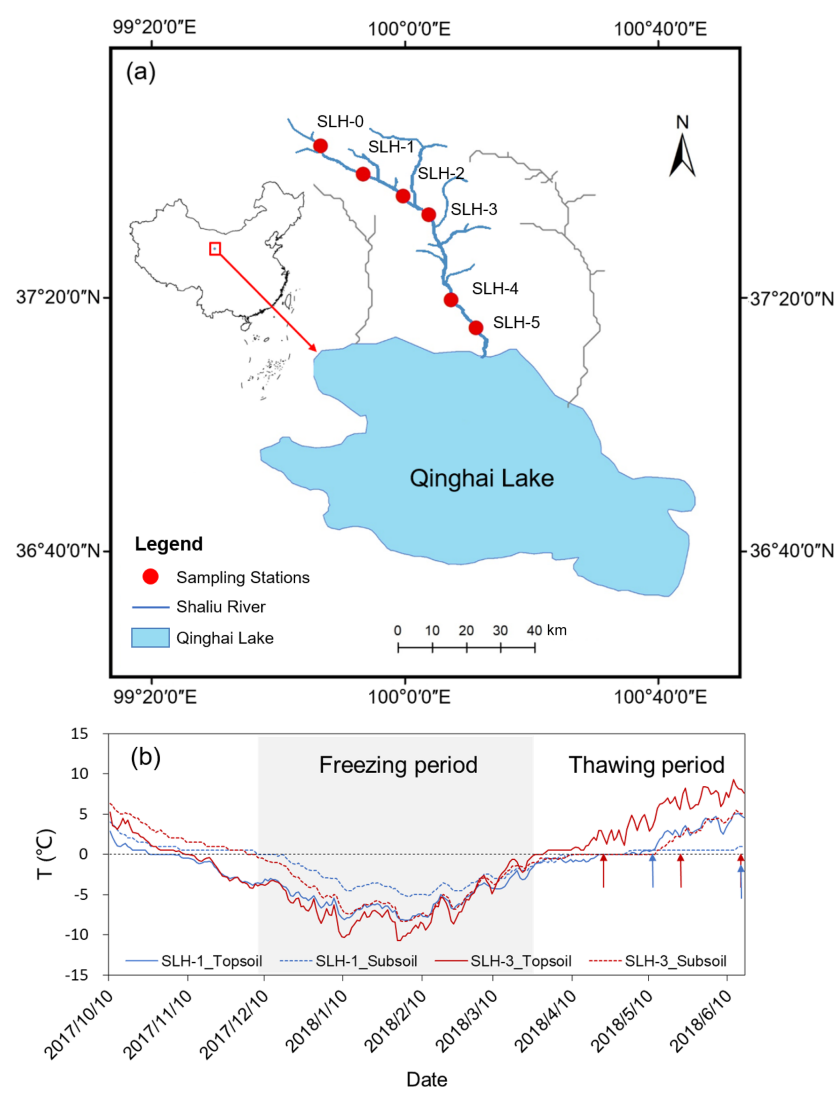

Figure 1. Sampling sites along the Shaliu River (a) and soil temperature $(T)$ at the depth of $10 \mathrm{~cm}$ (referred to as topsoil) and $40 \mathrm{~cm}$ (subsoil) at SLH-1 and SLH-3 stations (b). The map in panel (a) is processed with ArcGIS 10.0. The blue and red arrows in panel (b) indicate the sampling time for soil solution at SLH-1 and SLH-3 during thawing events, respectively.

trogen $(\mathrm{N})$ species and cations. The filters were freeze-dried for total suspended solids (TSSs), particulate organic carbon (POC), particulate inorganic carbon (PIC), particulate $\mathrm{N}$ and particulate lignin phenol measurements. The remaining filtrates were acidified to $\mathrm{pH} 2$ and extracted by solid phase extraction (SPE) for dissolved lignin phenol measurements.

To assess the influence of local hydrological events on riverine carbon, we further monitored spring thawing and a monsoonal precipitation. Specifically, soil temperature was monitored at 10 and $40 \mathrm{~cm}$ beneath the surface at SLH-1 and SLH-3 stations ( $\sim 150 \mathrm{~m}$ away from the river bank) at $2 \mathrm{~h}$ intervals from October 2017 to June 2018 using iButton temperature loggers (DS1922L, Wdsen, China). Spring thawing occurred in late April when soil temperature was $>0{ }^{\circ} \mathrm{C}$ (Fig. 1b). Soil solutions were collected two or three times from topsoil $(0-10 \mathrm{~cm})$ and subsoil $(30-40 \mathrm{~cm})$ in April-June 2018 using a pre-arranged ceramic head $(0.2 \mu \mathrm{m})$, which is a porewater sampling device composed of a porous ceramic head connected with a tube for pulling vacuum and retrieving sample. Soil leachates were also directly collected by putting 
acid-washed carboys under soil layers in exposed soil profiles in June 2018 (Wang et al., 2018). Soil solutions and leachates were filtered $(0.22 \mu \mathrm{m})$ immediately upon collection and preserved as previously described for DOC and dissolved lignin phenol analyses. For the monsoonal precipitation, river water was sampled at 15 min intervals (four times) at SLH-4 station during a precipitation event (lasting for $1 \mathrm{~h}$ ) in August 2015 when a rainfall of $1.0 \mathrm{~mm}$ was recorded on the same day at the Gonghe weather station near Shaliu River basin and filtered for the measurements of DOC, DIC, POC, PIC and TSS.

To investigate connections between riverine and soil organic matter within the basin, topsoil $(0-10 \mathrm{~cm})$ and subsoil $(40-60 \mathrm{~cm})$ samples were collected from five locations 150 $500 \mathrm{~m}$ away from the corresponding river sampling station in August 2015. At each location, three soil cores were collected from each of three random quadrats $(1 \times 1 \mathrm{~m}$; intervals $>500 \mathrm{~m}$ ) using a stainless-steel gravity corer (diameter of $5 \mathrm{~cm}$ ). Soils from the same depth and same quadrat were homogenized and shipped back to the laboratory. Freeze-dried soils were passed through a $2 \mathrm{~mm}$ sieve for soil organic carbon (SOC), soil $\mathrm{N}$ and soil lignin phenol measurements after removal of visible roots.

\subsection{Bulk chemical analysis}

The contents of riverine POC, particulate N, SOC and soil N were determined by elemental analyzer (Vario EL III, Germany) after fumigation with concentrated hydrochloric acid (HCl; Dai et al., 2019), and the analytical precision (standard deviation for repeated measurements of standards) was $\pm 0.1 \%$. POC concentration $\left(\mathrm{mg} \mathrm{L}^{-1}\right)$ was calculated based on POC content (\%OC) and TSS concentration. PIC was calculated by subtracting POC from total particulate carbon quantified by an elemental analyzer without fumigation.

The DOC, dissolved N and DIC concentrations were measured using a Multi N/C 3100 analyzer fitted with an autosampler (Analytik Jena, Germany). Specifically, water samples for DOC analysis were manually acidified to $\mathrm{pH}$ $<2$ with $\mathrm{HCl}$ and sparged automatically with oxygen $\left(\mathrm{O}_{2}\right)$ to remove inorganic carbon before DOC measurement via the high-temperature catalytic oxidation procedure on a Multi N/C 3100 analyzer. For DIC, water samples were acidified online using phosphoric acid $\left(\mathrm{H}_{3} \mathrm{PO}_{4}\right)$ with the $\mathrm{CO}_{2}$ analyzed by the non-scattering infrared detector on a Multi N/C 3100 analyzer. The analytical precision was $\pm 1 \%$ based on repeated measurements of standards. Inorganic $\mathrm{N}$ including ammonium $\left(\mathrm{NH}_{4}^{+}-\mathrm{N}\right)$, nitrate $\left(\mathrm{NO}_{3}^{-}-\mathrm{N}\right)$ and nitrite $\left(\mathrm{NO}_{2}^{-}-\right.$ $\mathrm{N})$ was determined colorimetrically on an AutoAnalyzer-3 (Bran \& Luebbe, Germany). Dissolved organic N (DON) was calculated by subtracting all inorganic $\mathrm{N}$ from dissolved $\mathrm{N}$. Major cations including calcium $\left(\mathrm{Ca}^{2+}\right)$ and magnesium $\left(\mathrm{Mg}^{2+}\right)$ were measured on an inductively coupled plasma mass spectrometer (ICP-MS, 7700X, Agilent, USA) after acidifying to $\mathrm{pH}<2$.

\subsection{Lignin phenol analysis}

Lignin phenols were analyzed using the alkaline copper oxide $(\mathrm{CuO})$ oxidation method to trace terrestrially derived OM (Hedges and Ertel, 1982). Dissolved lignin phenols were concentrated with SPE cartridges containing $5 \mathrm{~g}$ of sorption materials composed of octadecyl carbon moieties $\left(\mathrm{C}_{18}\right)$ chemically bonded to a silica support $\left(\mathrm{C}_{18}\right.$-SPE Mega Bond Elut; Agilent, USA). Cartridges were pretreated with methanol followed by acidified ( $\mathrm{pH}$ 2) Milli-Q water. Filtered (through a $0.7 \mu \mathrm{m}$ pre-combusted $\mathrm{GF} / \mathrm{F}$ filter) river water was acidified to $\mathrm{pH} 2$ using concentrated $\mathrm{HCl}$, amended with pure methanol to a final concentration of $0.5 \%(v / v)$ to improve SPE efficiency (Spencer et al., 2010a), thoroughly mixed and passed through the SPE cartridge with a peristaltic pump at a flow rate of $10 \mathrm{~mL} \mathrm{~min}^{-1}$ (Louchouarn et al., 2010). The extraction efficiency of the $\mathrm{C}_{18}$ cartridge for lignin phenols was around $80 \%-90 \%$ (Spencer et al., 2010a). All cartridges were dried and kept in a freezer in the dark until dissolved organic matter (DOM) was eluted with methanol and dried under nitrogen gas $\left(\mathrm{N}_{2}\right)$. Dried samples were mixed with $0.5 \mathrm{~g} \mathrm{CuO}, 50 \mathrm{mg}$ ammonium iron (II) sulfate hexahydrate $\left[\mathrm{Fe}\left(\mathrm{NH}_{4}\right)_{2}\left(\mathrm{SO}_{4}\right)_{2} \cdot 6 \mathrm{H}_{2} \mathrm{O}\right]$ and $15 \mathrm{mg}$ glucose (to avoid excessive oxidation), and soil solutions and leachates were mixed with the same reagents as well. All samples were mixed with $20 \mathrm{~mL}$ of $2 \mathrm{M} \mathrm{N}_{2}$-purged sodium hydroxide $(\mathrm{NaOH})$ solution in teflon-lined bombs at $170^{\circ} \mathrm{C}$ for $2.5 \mathrm{~h}$. The lignin oxidation products were spiked with a recovery standard (ethyl vanillin), acidified to $\mathrm{pH}<2$ with $12-\mathrm{M} \mathrm{HCl}$ and kept in the dark for $2 \mathrm{~h}$. Oxidation products were extracted with ethyl acetate three times, spiked with an internal standard (trans-cinnamic acid) and concentrated under $\mathrm{N}_{2}$ for further analysis. Lignin phenols, after converting to trimethylsilyl derivatives by reacting with $\mathrm{N}, \mathrm{O}-$ bis-(trimethylsilyl)trifluoroacetamide (BSTFA) and pyridine, were quantified on a gas chromatograph-mass spectrometer (GC-MS; Thermo Fisher Scientific, USA) using a DB$5 \mathrm{MS}$ column $(30 \mathrm{~m} \times 0.25 \mathrm{~mm}$ inner diameter; film thickness $0.25 \mu \mathrm{m}$ ) for separation (Dai et al., 2019). Quantification was achieved by comparing with recovery standards (ethyl vanillin) to account for compound loss during extraction procedures. In addition, TSS and soil samples were extracted using the same procedures as mentioned above without the addition of glucose.

Eight lignin-derived phenols, including vanillyl (V; vanillin, acetovanillone, vanillic acid), syringyl (S; syringaldehyde, acetosyringone, syringic acid) and cinnamyl (C; $p$-coumaric acid, ferulic acid) phenols, are used to represent the absolute $\left(\Sigma_{8}\right.$; in units of $\left.\mu \mathrm{g} \mathrm{L}^{-1}\right)$ and OC-normalized concentration $\left(\Lambda_{8}\right.$; in units of $\mathrm{mg} \mathrm{g}^{-1}$ OC) of lignin phenols. The acid-to-aldehyde ( $\mathrm{Ad} / \mathrm{Al})$ ratios of $\mathrm{V}$ and $\mathrm{S}$ phenols are used to indicate lignin oxidation (Opsahl and Benner, 1995), which typically increases with elevated degradation (Otto and Simpson, 2006) but may be affected by leaching and sorption processes as well (Hernes et al., 2007). 


\subsection{Carbon flux estimate from LOADEST}

The daily discharge was combined with measured DOC and DIC concentrations at SLH-4 station to model their fluxes using the USGS load estimator (LOADEST) program (Runkel et al., 2004; https://water.usgs.gov/software/loadest/, last access: 27 March 2021) within the LoadRunner software package (URL: https://environment.yale.edu/loadrunner/, last access: 27 March 2021). The best regression model with the lowest Akaike information criterion (AIC) and without variables for long-term change during the calibration period (i.e., models 1, 2, 4 and 6) within LOADEST was selected to fit the measured DOC (Eq. 1) and DIC fluxes (Eq. 2) for annual carbon flux estimate (Song et al., 2020; Tank et al., 2012; Zolkos et al., 2018, 2020):

$$
\begin{aligned}
& \ln (\text { DOC flux })=a_{0}+a_{1} \ln Q, \\
& \begin{aligned}
\ln (\text { DIC flux }) & =a_{0}+a_{1} \ln Q+a_{2} \ln Q^{2} \\
& +a_{3} \operatorname{Sin}(2 \pi \text { dtime })+a_{4} \operatorname{Cos}(2 \pi \text { dtime }),
\end{aligned}
\end{aligned}
$$

where flux is provided in $\mathrm{kg} \mathrm{d}^{-1}, Q$ is river discharge in cubic meters per second $\left(\mathrm{m}^{3} \mathrm{~s}^{-1}\right)$ multiplied by a conversion factor of $0.0283, \ln Q$ equals $\ln$ (streamflow) minus center of $\ln$ (streamflow), dtime equals decimal time minus center of decimal time and other parameters (i.e., $a_{0}, a_{1}, a_{2}, a_{3}, a_{4}$ ) are shown in Table S1. LOADEST can provide daily, monthly and annual fluxes using the adjusted maximum likelihood estimation (AMLE) approach (Song et al., 2020; Tank et al., 2012).

\subsection{Statistical analyses}

Normal distribution of data and homogeneity of variance were checked for all variables using the Shapiro-Wilk and Levene tests, respectively. Differences in river water parameters between the pre-monsoon and monsoon seasons were tested using the independent-sample $t$ test. Differences in the $\mathrm{Ad} / \mathrm{Al}$ ratios between topsoils and subsoils were analyzed by a paired $t$ test. Differences in the Ad/Al ratios between soil solutions and leachates at SLH-1 station during thawing events were determined using one-way ANOVA followed by a post hoc Duncan test. Differences in river water $\mathrm{pH}$ were checked by Mann-Whitney $U$ test due to nonnormal distribution of data. Pearson correlation was used to assess relationships between DIC and cation concentrations and between riverine carbon concentration and the distance of sampling sites from SLH-0, where autocorrelation of riverine carbon concentrations among samples was not significant based on the Durbin-Watson test. Differences and correlations were considered to be significant at a level of $p<0.05$. All statistical analyses were conducted using SPSS 25 (SPSS, Chicago, USA).
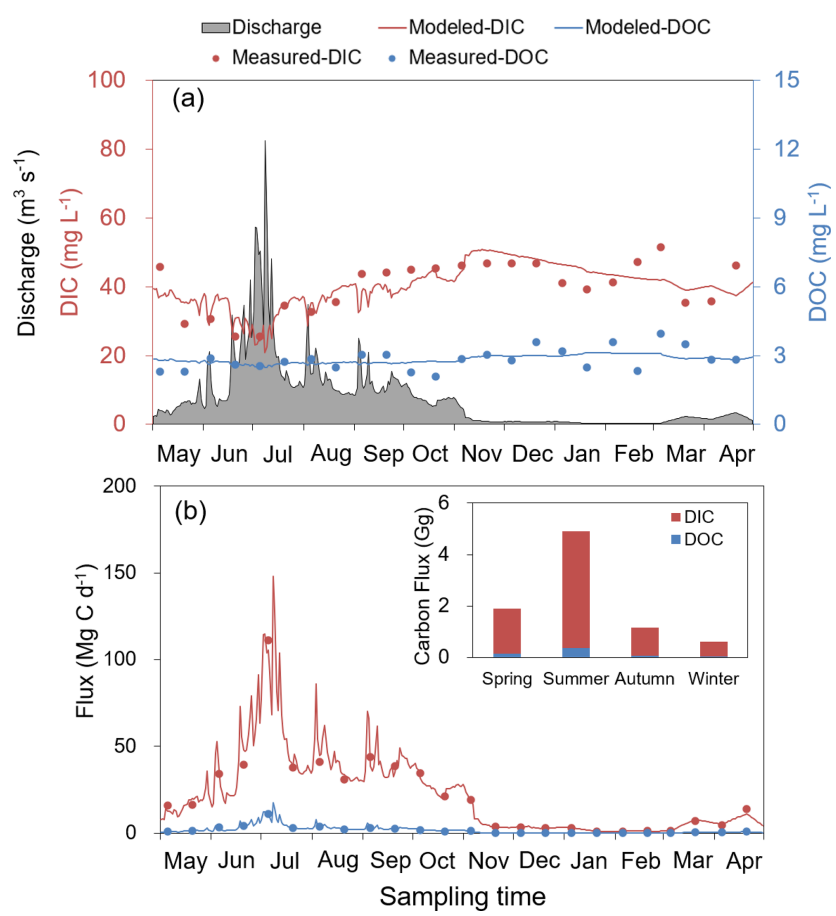

Figure 2. Discharge, dissolved inorganic carbon (DIC), and dissolved organic carbon (DOC) concentrations (a) and fluxes (b) exported from Shaliu River at SLH-4 station from May 2015 to April 2016. The modeled concentrations in (a) and modeled fluxes in (b) are derived from load estimator (LOADEST). The inserted columns in panel (b) show the seasonal variations in carbon fluxes classified as follows: spring (May to June), summer (July to September), autumn (October to November) and winter (December to the next April).

\section{Results}

\subsection{Discharges and carbon fluxes}

The total annual discharge of Shaliu River at SLH-4 station was $2.4 \times 10^{8} \mathrm{~m}^{3}$ from 2015 to 2016 . Its daily discharge ranged from 0.25 to $82.40 \mathrm{~m}^{3} \mathrm{~s}^{-1}$, following a normal distribution with a maximum of $82.40 \mathrm{~m}^{3} \mathrm{~s}^{-1}$ in the monsoon season (Fig. 2a). DIC concentration at SLH-4 station showed a large intra-annual variability from 20.8 to $50.9 \mathrm{mg} \mathrm{L}^{-1}$ with a minimum value in the monsoon season and had a negative relationship with river discharge (Fig. 2a). Conversely, DOC concentrations were relatively constant and fluctuated around 2.5-3.1 mg L$~^{-1}$ (Fig. 2a). Accordingly, the DIC and DOC fluxes at SLH-4 station were estimated to be 8.0 and $0.6 \mathrm{Gg} \mathrm{yr}^{-1}\left(1 \mathrm{Gg}=10^{9} \mathrm{~g}\right)$, respectively, both of which were highest in summer, accounting for $58 \%-60 \%$ of the corresponding annual fluxes (Fig. 2b). Moreover, annual DIC flux was more than 10 times larger than the DOC flux in the Shaliu River and constituted $90 \%$ of the total dissolved carbon flux. 


\subsection{River water properties and lignin phenols}

River water was slightly alkaline with higher $\mathrm{pH}$ values in the pre-monsoon $(8.4 \pm 0.04)$ than monsoon season $(7.7 \pm 0.2)$ in the Shaliu River $(p<0.05$; Table 1). DO concentration was also higher in the pre-monsoon $\left(5.91-6.76 \mathrm{mg} \mathrm{L}^{-1}\right)$ than monsoon season $\left(4.39-5.87 \mathrm{mg} \mathrm{L}^{-1} ; p<0.05\right)$. Consistent with the annual monitoring results, DIC was the dominant carbon species, accounting for approximately $90 \%$ of the total carbon, followed by DOC, POC and PIC, respectively (Fig. S2a). DOC concentration was higher in the monsoon than pre-monsoon season, while both PIC and POC concentrations were higher in pre-monsoon season $(p<0.05$; Fig. S2a) due to the higher TSS in the majority of sampling sites (Table 1). The DOC/POC ratio was lower in the premonsoon than monsoon season ( $p<0.05$; Table 1$)$. The POC concentration was positively related to TSS ( $p<0.05$; Table 1), and DIC concentration had a positive correlation with cation $\left(\mathrm{Ca}^{2+}+\mathrm{Mg}^{2+}\right)$ in both seasons $(p<0.05$; Fig. S2b). Both dissolved (i.e., DOC and DIC) and particulate carbon (i.e., POC and PIC) concentrations fluctuated along the Shaliu River in the monsoon season, while most of them increased significantly downstream in the pre-monsoon season $(p<0.05$; Fig. 3a) except for a marginally significant increasing trend for POC ( $p=0.07$; Fig. S3).

The absolute concentration of dissolved lignin phenols $\left(\Sigma_{8}\right)$ increased longitudinally from $1.33 \mu \mathrm{g} \mathrm{L}^{-1}$ at SLH-0 to $4.77 \mu \mathrm{g} \mathrm{L}^{-1}$ at SLH-5 in the pre-monsoon season, while it peaked at SLH-2 $\left(4.13 \mu \mathrm{g} \mathrm{L}^{-1}\right)$ and decreased to $1.35 \mu \mathrm{g} \mathrm{L}^{-1}$ in the monsoon season (Fig. 3b). The absolute concentration of particulate lignin phenols showed similar trends with dissolved lignin, which increased downstream from 1.07 to $3.44 \mu \mathrm{g} \mathrm{L}^{-1}$ in the pre-monsoon season and peaked at SLH-2 in the monsoon season. The $(\mathrm{Ad} / \mathrm{Al})_{\mathrm{S}}$ ratios showed no significant difference between dissolved and particulate lignin phenols, while the $(\mathrm{Ad} / \mathrm{Al})_{\mathrm{V}}$ ratios of dissolved lignin phenols ranging from 0.89 to 1.96 were significantly higher than that in particulate lignin phenols $(0.46-0.95 ; p<0.05$; Fig. 3d). Both $(\mathrm{Ad} / \mathrm{Al})_{\mathrm{V}}$ and $(\mathrm{Ad} / \mathrm{Al})_{\mathrm{S}}$ ratios of dissolved lignin phenols, fluctuating along the Shaliu River, were consistently lower in the pre-monsoon than monsoon season $(p<0.05$; Fig. 3d). After examining lignin phenols in the soils of the Shaliu basin, we found spatially variable concentrations of lignin phenols (Fig. 4a) but consistently higher $(\mathrm{Ad} / \mathrm{Al})_{\mathrm{V}}$ and $(\mathrm{Ad} / \mathrm{Al})_{\mathrm{S}}$ ratios in the topsoil than subsoil at all sampling sites $(p<0.05$; Fig. $4 \mathrm{~b}-\mathrm{c})$.

\subsection{Carbon variations during local hydrological events}

To reveal the riverine carbon variations induced by soil-river water transfer in the Shaliu River, we focused on two important hydrological events. First, we monitored DOC and lignin phenol concentrations in soil solutions along with the progress of thawing (when soil temperature reached $>0{ }^{\circ} \mathrm{C}$ ). Topsoil DOC and lignin phenols showed an increasing (albeit not statistically significant) trend from 19.1 to $22.0 \mathrm{mg} \mathrm{L}^{-1}$ and from 44.9 to $57.6 \mu \mathrm{g} \mathrm{L}^{-1}$ from 11 May to 17 June at SLH-1 station, respectively (Fig. 5a-c). Similarly, topsoil DOC increased from 22.4 to $29.4 \mathrm{mg} \mathrm{L}^{-1}$ from 22 April to 17 June at SLH-3 station (Fig. 5b). Subsoil-derived DOM was gradually released with thawing, indicated by the increase in DOC (or lignin phenol) concentration from not detectable (frozen) on 11 May to $13.3 \mathrm{mg} \mathrm{L}^{-1}$ (lignin phenols $=23.1 \mu \mathrm{g} \mathrm{L}^{-1}$ ) on 17 June at SLH-1 station and from not detectable on 22 April to $22.1 \mathrm{mg} \mathrm{L}^{-1}$ on 22 May at SLH3 station (Fig. 5a-c). Furthermore, lignin $\mathrm{Ad} / \mathrm{Al}$ ratios were lower in the leachates of thawed soils than in the topsoil solution $(p<0.05)$ but similar to the subsoil solution at SLH-1 station (Fig. 5d-e), indicating a significant contribution of deep soil DOM to the leachate. Concurrently, riverine DOC increased from 2.3 to $3.1 \mathrm{mg} \mathrm{L}^{-1}$ on 11 May to 17 June and from 1.9 to $3.9 \mathrm{mg} \mathrm{L}^{-1}$ on 22 April to 17 June at SLH-1 and SLH-3 stations (Fig. 5a-b). Second, a typically local precipitation event lasting for $\sim 1 \mathrm{~h}$ at SLH-4 station was monitored to investigate the influence of precipitation on riverine carbon transport. With the start of rain, riverine DOC concentration increased from 2.0 to $3.3 \mathrm{mg} \mathrm{L}^{-1}$ within $0.5 \mathrm{~h}$ due to flushing and leaching of terrestrially derived $\mathrm{OM}$ and then decreased to $2.1 \mathrm{mg} \mathrm{L}^{-1}$ at the end of precipitation event due to dilution by rainwater (Table 2). Simultaneously, POC and PIC concentrations increased from 0.36 to $0.46 \mathrm{mg} \mathrm{L}^{-1}$ and from 0.03 to $0.06 \mathrm{mg} \mathrm{L}^{-1}$ accompanied by an increase in TSS concentrations from 5.8 to $7.4 \mathrm{mg} \mathrm{L}^{-1}$ (Table 2).

\section{Discussion}

\subsection{Riverine carbon fluxes in the Shaliu River}

In contrast to Arctic rivers with a pronounced spring freshet from May to June, both DOC and DIC fluxes in the Shaliu River were highest from July to August (accounting for $58 \%-60 \%$ of the corresponding annual fluxes; Fig. 2a-b) due to the maximum discharge caused by frequent precipitation events in the monsoon season (Fig. S1; Zeng et al., 2019). DIC, mainly composed of bicarbonate and carbonate based on the river water $\mathrm{pH}$ values (Table 1; Liu et al., 2020), was the dominant form of dissolved riverine carbon. Its proportion in dissolved riverine carbon is generally higher than tropical ( $40 \%$; Huang et al., 2012) and Arctic rivers (52\%-70\%; Striegl et al., 2007; Prokushkin et al., 2011; Guo et al., 2012) but similar to rivers sourced from the Qinghai-Tibetan Plateau including the upper Yangtze River, Yellow River and their tributaries (Cai et al., 2008; Gao et al., 2019; Song et al., 2019, 2020). The distinct lithology (such as limestone and sandstone) within the Shaliu River catchment results in high carbonate and silicate weathering rate (Xiao et al., 2013), which is an important source of DIC in river water. The connection of DIC in the Shaliu River to high chemical weathering rate on the Qinghai-Tibetan Plateau is 
Table 1. River water properties along the Shaliu River.

\begin{tabular}{|c|c|c|c|c|c|c|c|c|c|c|c|c|c|}
\hline \multirow[t]{2}{*}{ Sample } & & Long. & & & $\mathrm{pH}$ & & DO & TSS & DIN & DON & \multirow{2}{*}{$\begin{array}{l}\text { Carbon content } \\
\qquad(\mathrm{POC})(\%)\end{array}$} & \multirow{2}{*}{$\begin{array}{l}\text { DOC/ } \\
\text { POC }\end{array}$} & \multirow{2}{*}{$\begin{array}{l}\text { DOC/ } \\
\text { DON }\end{array}$} \\
\hline & $\left({ }^{\circ} \mathrm{N}\right)$ & $\left({ }^{\circ} \mathrm{E}\right)$ & (m a.s.l.) & $\left({ }^{\circ} \mathrm{C}\right)$ & & $\left(\mu \mathrm{scm}^{-1}\right)$ & \multicolumn{4}{|c|}{$\left(\mathrm{mg} \mathrm{L}^{-1}\right)$} & & & \\
\hline \multicolumn{14}{|c|}{ Pre-monsoon season (May 2015) } \\
\hline SLH-0 & 37.73 & 99.78 & 3846 & 10.4 & 8.5 & 369 & 6.2 & 13.2 & NA & NA & 7.80 & 1.25 & NA \\
\hline SLH-1 & 37.66 & 99.89 & 3678 & 8.2 & 8.4 & 267 & 6.4 & 15.2 & NA & NA & 8.29 & 1.09 & NA \\
\hline SLH-2 & 37.60 & 100.00 & 3553 & 8.8 & 8.5 & 302 & 6.1 & 18.6 & NA & NA & 5.54 & 1.74 & NA \\
\hline SLH-3 & 37.55 & 100.06 & 3485 & 7.7 & 8.4 & 417 & 6.8 & 23.4 & NA & NA & 7.48 & 1.14 & NA \\
\hline SLH-4 & 37.33 & 100.12 & 3293 & 11.5 & 8.4 & 355 & 6.6 & 25.8 & NA & NA & 5.47 & 1.63 & NA \\
\hline SLH-5 & 37.25 & 100.19 & 3243 & 12.9 & 8.2 & 342 & 5.9 & 33.4 & NA & NA & 6.98 & 0.99 & NA \\
\hline Mean & & & & $9.9 \mathrm{a}$ & $8.4 \mathrm{a}$ & $342 \mathrm{a}$ & $6.3 \mathrm{a}$ & $21.6 \mathrm{a}$ & NA & NA & $6.92 \mathrm{a}$ & $1.31 \mathrm{~b}$ & NA \\
\hline \multicolumn{14}{|c|}{ Monsoon season (August 2015) } \\
\hline SLH-0 & 37.73 & 99.78 & 3846 & 8.8 & 7.6 & 339 & 5.3 & 5.2 & 0.8 & 0.3 & 5.00 & 9.39 & 10.9 \\
\hline SLH-1 & 37.66 & 99.89 & 3678 & 10.0 & 7.7 & 305 & 5.3 & 6.2 & 1.2 & 0.4 & 7.26 & 4.89 & 6.8 \\
\hline SLH-2 & 37.60 & 100.00 & 3553 & 9.3 & 7.5 & 313 & 5.8 & 22.4 & 1.5 & 0.4 & 4.96 & 2.43 & 7.3 \\
\hline SLH-3 & 37.55 & 100.06 & 3485 & 8.0 & 7.5 & 377 & 5.9 & 9.8 & 3.0 & 0.5 & 5.20 & 4.32 & 5.2 \\
\hline SLH-4 & 37.33 & 100.12 & 3293 & 17.9 & 8.4 & 355 & 4.4 & 26.8 & 1.6 & 0.3 & 5.63 & 1.63 & 10.5 \\
\hline Mean & & & & $10.8 \mathrm{a}$ & $7.7 \mathrm{~b}$ & $338 \mathrm{a}$ & $5.3 b$ & $14.1 \mathrm{a}$ & 1.6 & 0.4 & $5.61 b$ & $4.54 \mathrm{a}$ & 8.2 \\
\hline
\end{tabular}

Different lowercase letters indicate significant differences between the pre-monsoon and monsoon seasons $(p<0.05)$. Lat., latitude; Long., longitude; $E$, elevation; $T$, water temperature; Cond., conductivity; DO, dissolved oxygen; TSS, total suspended solid; DOC, dissolved organic carbon; POC, particulate organic carbon; DIN, dissolved inorganic nitrogen; DON, dissolved organic nitrogen; DOC/POC, ratio of DOC to POC; DOC/DON, the atomic ratio of DOC to DON; a.s.1., above sea level; NA, not analyzed.

Table 2. River water properties at the SLH-4 station of Shaliu River during a precipitation event in August 2015.

\begin{tabular}{|c|c|c|c|c|c|c|c|c|c|c|}
\hline \multirow[t]{2}{*}{ Sample } & \multirow{2}{*}{$\begin{array}{r}\text { Sampling time } \\
\text { (h) }\end{array}$} & \multirow{2}{*}{$\begin{array}{r}T \\
\left({ }^{\circ} \mathrm{C}\right)\end{array}$} & \multirow[t]{2}{*}{$\mathrm{pH}$} & \multirow{2}{*}{$\begin{array}{r}\text { Cond. } \\
\left(\mu \mathrm{sm}^{-1}\right)\end{array}$} & DO & TSS & DIC & DOC & PIC & POC \\
\hline & & & & & \multicolumn{6}{|c|}{$\left(\mathrm{mg} \mathrm{L}^{-1}\right)$} \\
\hline SLH-4 & 0.25 & 11.4 & 8.2 & 386 & 5.9 & 5.8 & 37.76 & 2.04 & 0.03 & 0.36 \\
\hline SLH-4 & 0.50 & 11.1 & 8.3 & 381 & 5.6 & 6.2 & 37.43 & 3.26 & 0.04 & 0.44 \\
\hline SLH-4 & 0.75 & 11.0 & 8.3 & 384 & 5.5 & 7.0 & 37.24 & 3.21 & 0.04 & 0.42 \\
\hline SLH-4 & 1.00 & 11.5 & 8.3 & 384 & 5.2 & 7.4 & 37.96 & 2.06 & 0.06 & 0.46 \\
\hline Mean & & 11.3 & 8.3 & 384 & 5.6 & 6.6 & 37.60 & 2.64 & 0.04 & 0.42 \\
\hline
\end{tabular}

$T$, water temperature; Cond., conductivity; DO, dissolved oxygen; TSS, total suspended solid; DIC, dissolved inorganic carbon; DOC, dissolved organic carbon; PIC, particulate inorganic carbon; POC, particulate organic carbon.

further reflected by the high riverine $\mathrm{Ca}^{2+}$ and $\mathrm{Mg}^{2+}$ concentrations (Zhang et al., 2013) and their positive correlations with DIC ( $p<0.05$; Fig. S2b). The negative correlation of DIC concentration with river discharge at SLH-4 station (Fig. 2a) indicates interactive impacts on hydrology by precipitation and thawing. Specifically, the inputs of subsurface flow and groundwater containing high weathering products (including DIC) under base flow conditions (including during thawing) in this permafrost-affected watershed (Walvoord and Striegl, 2007; Giesler et al., 2014) result in relatively high DIC concentrations. By contrast, riverine DIC concentration decreases with discharge in the monsoon season from 2015 to 2016 likely due to the dilution effects of rainwater, which normally has a lower DIC concentration relative to stream water (Song et al., 2019).
DOC was the second most abundant riverine carbon with a lower concentration in the Shaliu River than most Arctic rivers (Mann et al., 2016; Amon et al., 2012; Spencer et al., 2008), only accounting for $7 \%$ of total riverine carbon. However, its concentration is equivalent to the upper Yangtze, Yellow, Lancang and Yarlung Zangbo rivers $(\mathrm{Qu}$ et al., 2017; Ran et al., 2013; Liu et al., 2021). The low DOC concentration reflects the relatively low SOC density in the alpine grasslands of the Qinghai-Tibetan Plateau $\left(9.05 \mathrm{~kg} \mathrm{C} \mathrm{m}^{-2}\right.$ in $0-100 \mathrm{~cm}$ depth; Yang et al., 2008) compared to most Arctic river basins containing organic-matterrich peatlands and deposits $\left(32.2-69.6 \mathrm{~kg} \mathrm{C} \mathrm{m}^{-2}\right.$; Tarnocai et al., 2009). The DOC/DON ratios in the Shaliu River were generally lower than the global riverine average (14; Harrison et al., 2005; Seitzinger et al., 2005), potentially indicating high biodegradability of riverine DOM (Wiegner et 

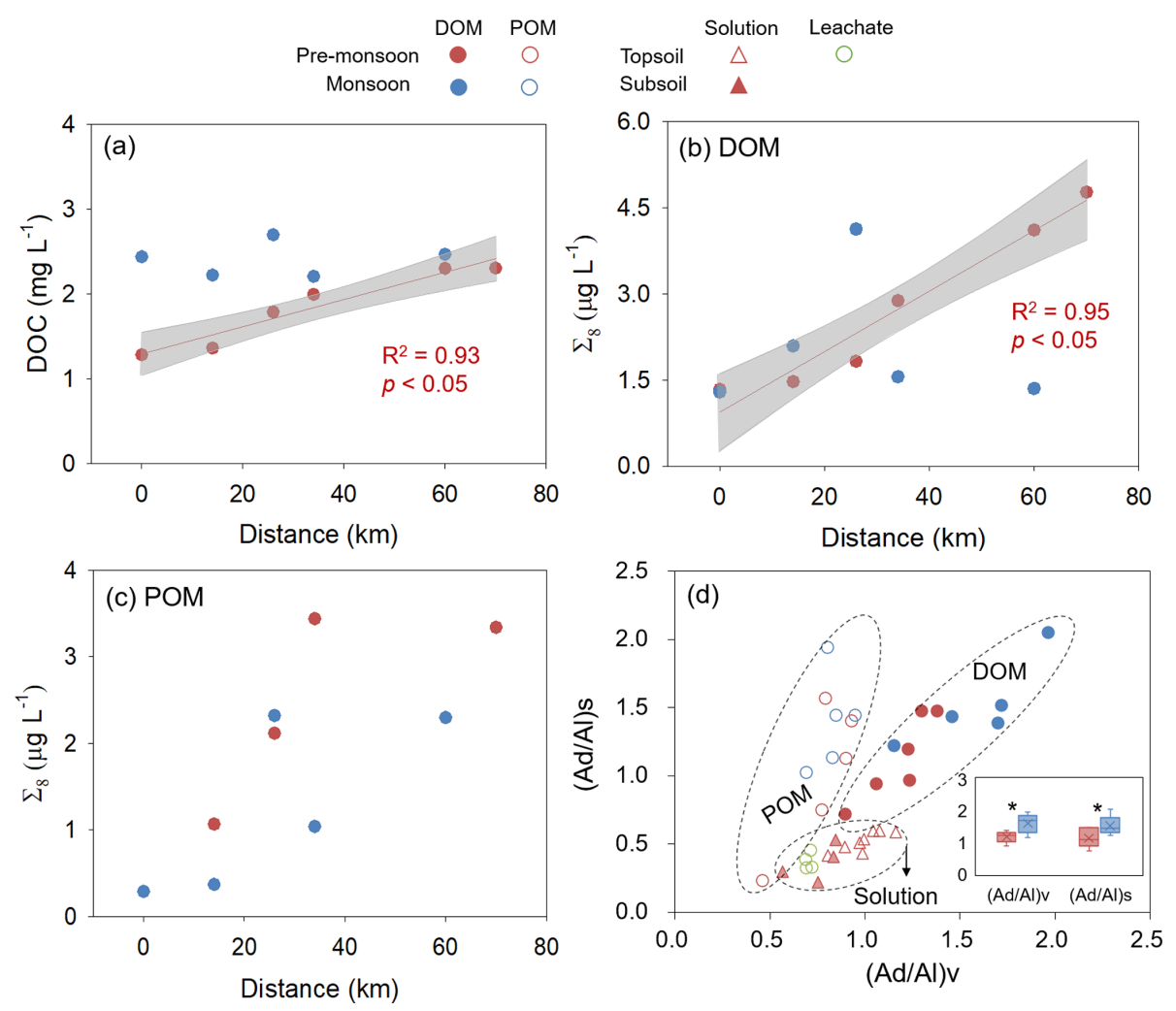

Figure 3. Variations in dissolved organic carbon (DOC) in Shaliu River water (a), absolute concentration of lignin phenols $\left(\Sigma_{8}\right)$ in riverine dissolved organic matter (DOM; b) and particulate organic matter (POM; c) during the pre-monsoon and monsoon seasons in 2015. The acid-to-aldehyde (Ad/Al) ratios of syringyl (S) and vanillyl (V) phenols in the riverine DOM, POM, soil solutions and leachates (d). The abscissa in panels (a), (b) and (c) mean the distance of sampling sites from SLH-0. The red lines in panels (a) and (b) correspond to the linear regression of data $(p<0.05)$, and the grey shaded regions in panels (a) and (b) show $95 \%$ confidence intervals. The inserted box in (d) is the comparison of $(\mathrm{Ad} / \mathrm{Al})_{\mathrm{V}}$ and $(\mathrm{Ad} / \mathrm{Al})_{\mathrm{S}}$ ratios of dissolved lignin phenols between pre-monsoon and monsoon seasons, respectively, with asterisks indicating significant differences (independent sample $t$ tests, $n=5, p<0.05$ ). The solid bar and cross in the inserted box mark the median and mean of each dataset, respectively. The upper and lower ends of the box denote percentiles 0.25 and 0.75 , respectively.

al., 2006), which may contribute to the low DOC concentration in this river as well. Furthermore, DOC concentrations showed no consistent relationship with river discharge throughout the year, while it showed opposite relationships with river discharge in early versus late pre-monsoon seasons (Fig. S4). Snowmelt in the early pre-monsoon season (early April) may dilute the base-flow DOC, resulting in a decreasing trend with discharge. By comparison, thawing of frozen soils in late pre-monsoon season (late April to June) releases more frozen carbon and thus results in an increasing trend of DOC with discharge.

\subsection{Spatial-temporal variation in riverine carbon in the Shaliu River}

The concentrations of dissolved and particulate carbon fluctuated along the Shaliu River in the monsoon season while they increased significantly downstream in the pre-monsoon season. Similarly, the absolute concentration of dissolved and particulate lignin phenols peaked at SLH-2 in the mon- soon season, but they showed a downstream increasing trend in the pre-monsoon season. These trends stand in contrast to the downstream accumulation of riverine carbon in the highflow conditions and increasing degradation in the low-flow conditions observed in other rivers including Zambezi River (Lambert et al., 2016) and a tributary of Yukon River (Dornblaser and Striegl, 2015), suggesting unique seasonality in the spatial variations in riverine carbon in the Shaliu River. In addition, the higher particulate carbon was directly related to the higher TSS concentrations in the pre-monsoon than monsoon season. Thermal erosion during thawing is the most important pathway supplying particulates and weathering products into the river on the Qinghai-Tibetan Plateau (Wang et al., 2016), which may explain the high particulate concentration in the pre-monsoon season. In contrast, other than aged DOC sourced from thawed soils, exudates from plant roots are also an important supply to riverine DOC. Although we did not measure root exudates, we postulate that the higher riverine DOC during the monsoon than pre-monsoon sea- 


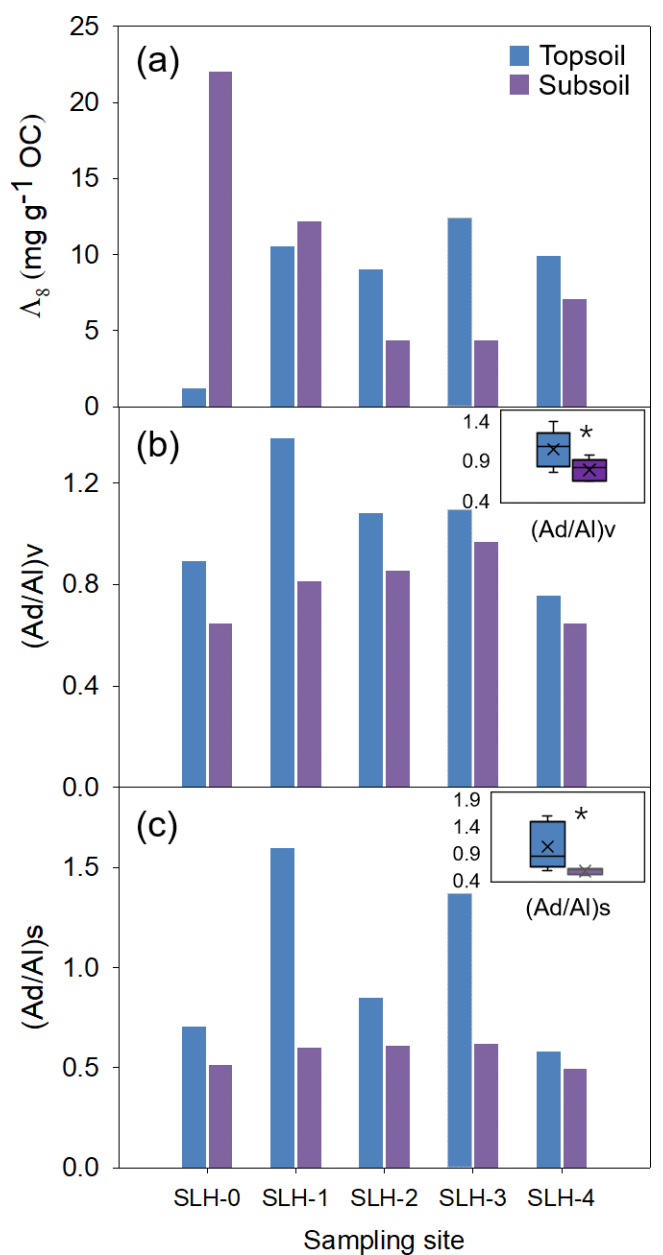

Figure 4. Concentration of lignin phenols normalized by organic carbon (OC) $\left(\Lambda_{8}, \mathbf{a}\right)$. The acid-to-aldehyde (Ad/Al) ratios of vanillyl $(\mathrm{V}, \mathbf{b})$ and syringyl $(\mathrm{S}, \mathbf{c})$ phenols in the soil of the Shaliu River basin. The solid bar and cross in the inserted boxes in panels (b) and (c) mark the median and mean of each dataset, respectively. The upper and lower ends of boxes denote percentiles 0.25 and 0.75 , respectively. Asterisks indicate significant differences between topsoil $(0-10 \mathrm{~cm})$ and subsoil $(40-60 \mathrm{~cm}$; paired-sample $t$ tests, $n=5$, $p<0.05$ ). The legends in panel (a) also apply to other panels.

son is related to increased plant growth and exudation in the growing season.

Both $(\mathrm{Ad} / \mathrm{Al})_{\mathrm{V}}$ and $(\mathrm{Ad} / \mathrm{Al})_{\mathrm{S}}$ ratios of dissolved lignin phenols were lower in the pre-monsoon season than monsoon season, consistent with the Arctic rivers (Amon et al., 2012) but different from the invariant or opposite patterns between seasons in tropical rivers including Congo and Oubangui (Spencer et al., 2010b; Bouillon et al., 2012). The higher acid-to-aldehyde ratio of lignin phenols is commonly attributed to increased photo- or microbial oxidation of lignin. However, photo- and microbial oxidation may be partially constrained by the short residence time (indicated by high discharge in monsoon season) and low temperature in this alpine river (average water temperature of $10.8^{\circ} \mathrm{C}$
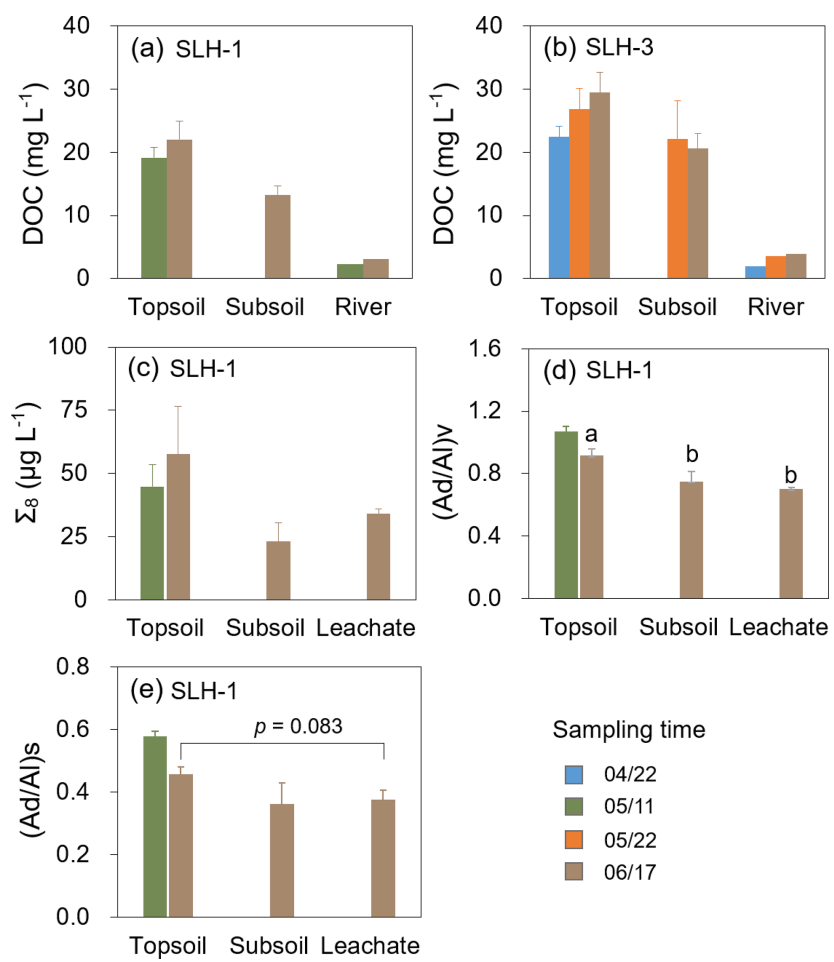

Figure 5. Variations in dissolved organic carbon (DOC) in soil solutions and river water at SLH-1 (a) and SLH-3 (b) stations. Absolute concentration of lignin phenols $\left(\Sigma_{8}\right)$ in soil solutions and leachates at SLH-1 station (c), and the variations in the acid-toaldehyde $(\mathrm{Ad} / \mathrm{Al})$ ratios of syringyl $(\mathrm{S})$ and vanillyl $(\mathrm{V})$ phenols in soil solutions and leachates at SLH-1 station (d-e) during the thawing period in 2018. Error bars in panels (a-e) represent the standard error of the mean $(n=4)$. Lowercase letters in panel $(\mathbf{d})$ indicate different levels of Ad/Al ratio among the leachates, topsoil and subsoil solutions (one-way ANOVA, $n=4, p<0.05$ ) while $p$ values in panel (e) indicate the marginal difference of the $\mathrm{Ad} / \mathrm{Al}$ ratio between topsoil solutions and leachates.

in the monsoon season; Table 1). Alternatively, the acid-toaldehyde $(\mathrm{Ad} / \mathrm{Al})$ ratios of lignin phenols in topsoil were higher than those in the subsoil, in contrast to the increase in Ad/Al ratios with soil depth typically reported in other soils (Otto and Simpson, 2006). Our previous research also finds higher $\mathrm{Ad} / \mathrm{Al}$ ratios in topsoil than subsoil in an alpine grassland on the Qinghai-Tibetan Plateau due to the influence of dominant vegetation (i.e., shallow-rooted $K$. humilis) having high Ad/Al ratios in its roots (Jia et al., 2019). Here, the Shaliu River basin is dominated by shallow-rooted $K$. humilis as well (Li et al., 2013), likely leading to the higher Ad/Al ratios in topsoil. Streamflow is supplied by snowmelt water via surface and near-surface pathways in the early pre-monsoon season when temperature ranges from -2 to $0^{\circ} \mathrm{C}$ (Tetzlaff et al., 2015) and thus contains amounts of carbon from surface soils, while streamflow shifts from surface meltwater to water stored in subsurface frozen soils (i.e., an increasing contribution of deep soil water) as air and soil temperature rises. 
This transition in stream water sources in the pre-monsoon season suggests that the contribution of deep soil water to streamflow increases with the progress of thawing events (Carey and Quinton, 2004; Tetzlaff et al., 2015). In combination with the different $\mathrm{Ad} / \mathrm{Al}$ ratios between pre-monsoon and monsoon seasons, we postulate that topsoil makes a relatively larger contribution to riverine DOM in the monsoon season likely through increased surface runoff, resulting in higher acid-to-aldehyde ratios of dissolved lignin in the river compared to the pre-monsoon season.

\subsection{Riverine carbon variations influenced by local hydrological events}

The unique spatial-temporal variations in riverine carbon mentioned above are likely related to the high sensitivity of the Shaliu River to local hydrological processes (Biggs et al., 2017), including sporadic occurrences of local precipitation in the monsoon season (Wu et al., 2016) and thawing of frozen soils in the pre-monsoon (spring) season. Specifically, the downstream increase in riverine carbon in the premonsoon season (April-May) was anticipated to be related to spring thawing releasing DOC previously frozen in the soil. The observed increase in soil DOC and lignin phenols in topsoil solutions over time reflects carbon release from previously frozen topsoil and/or inputs via lateral flow paths during thawing. Combined with the release of subsoil-derived DOM proved by subsoil DOC availability and lignin phenol $\mathrm{Ad} / \mathrm{Al}$ ratios, these results indicate the release of frozen DOM during thawing events. The riverine DOC shows a high synchronousness with the increase in soil DOM, partially explaining the downstream increase in DOC along the Shaliu River in the pre-monsoon season. In particular, as the upstream Shaliu basin has a slightly higher elevation, soil temperature is slightly lower in the upstream than downstream in spring $\left(-1.2-0{ }^{\circ} \mathrm{C}\right.$ at SLH-1 versus $0-2.9^{\circ} \mathrm{C}$ at $\mathrm{SLH}-3$ on March 26 to April 20; Fig. 1b), leading to earlier and stronger thawing of soil in the lower basin. This spatiotemporal variation in freezing-thawing periods affects riverine carbon transport in the following two aspects. First, the earlier thawing of frozen soils downstream (at a lower elevation) in the Shaliu basin enhances soil carbon release compared with the upstream basin, likely leading to an increasing carbon concentration along the river continuum (Song et al., 2019; Vonk et al., 2015). Second, the thawing depth of frozen soils increases with time in the pre-monsoon season due to increasing temperature, thus causing an increasing riverine carbon concentration with thawing events (Wang et al., 2017; Song et al., 2019). Overall, inputs of DOC from thawed soil increase downstream in spring, leading to the downstream increase in riverine carbon in this alpine river.

In contrast, sporadic local precipitation events occur frequently during the monsoon season, leading to fast hydrological variations reflected by increasing TSS concentrations over time in the $1 \mathrm{~h}$ precipitation events (Beel et al., 2018).
The rapid response of riverine DOC and POC to the above hydrological alterations indicates the high sensitivity of riverine carbon to short-term precipitation. According to historical precipitation records (Fig. S1), more than $90 \%$ of the annual precipitation occurs in the monsoon season from June to September, mainly in the form of short-lasting and weak precipitation events (intensity $<5 \mathrm{~mm}$; Wu et al., 2016), thus frequently influencing local soil-stream carbon transfer processes. Along the Shaliu River, DOC concentrations in the monsoon season showed no regular downstream variations, likely related to variable local precipitation events frequently occurring in the Shaliu River basin in the summer (Yao et al., 2013; Wu et al., 2016).

\section{Conclusions}

In conclusion, combining annual flux monitoring and dense spatial sampling along the Shaliu River in two contrasting seasons, we provide a benchmark assessment of riverine carbon variations in an alpine catchment on the Qinghai-Tibetan Plateau. We show that DIC constitutes the majority (>87\%) of riverine carbon in this alpine river, dominated by carbon fluxes in the monsoonal summer. In addition, riverine carbon in the Shaliu River increased downstream in the pre-monsoon season due to increasing contribution of organic matter derived from thawed soils while organic matter inputs induced by sporadic precipitation during the monsoon season led to fluctuating concentrations of riverine carbon in the summer. These results indicate a higher sensitivity of riverine DIC than DOC concentration in the alpine river to local hydrological events, and DOC source appears to change as well. Given projected climate warming on the Qinghai-Tibetan Plateau (Chen et al., 2013), thawing of permafrost and alterations of precipitation regimes may significantly influence the alpine headwater carbon transport, with critical effects on the biogeochemical cycles of the downstream rivers. On the other hand, the alpine catchments may be utilized as sentinels for climate-induced changes in the hydrological pathways and/or biogeochemistry of the small basin. Both aspects deserve further research attention in the future.

Data availability. All data are available within this paper and in the Supplement.

Supplement. The supplement related to this article is available online at: https://doi.org/10.5194/bg-18-3015-2021-supplement.

Author contributions. XF designed the study. XW performed geochemical and lignin phenol analyses and analyzed related data. TL wrote the manuscript. XW and TL contributed equally to this work. All authors contributed to the field sampling. 
Competing interests. The authors declare that they have no conflict of interest.

Acknowledgements. We thank the editor Ji-Hyung Park and the two anonymous referees for the improvement of this paper.

Financial support. This research has been supported by the National Basic Research Program of China (grant no. 2019YFA0607303) and the National Natural Science Foundation of China (grant nos. 42025303, 41973075, and 31988102).

Review statement. This paper was edited by Ji-Hyung Park and reviewed by two anonymous referees.

\section{References}

Amon, R. M. W., Rinehart, A. J., Duan, S., Louchouarn, P., Prokushkin, A., Guggenberger, G., Bauch, D., Stedmon, C., Raymond, P. A., Holmes, R. M., McClelland, J. W., Peterson, B. J., Walker, S. A., and Zhulidov, A. V.: Dissolved organic matter sources in large Arctic rivers, Geochim. Cosmochim. Ac., 94, 217-237, https://doi.org/10.1016/j.gca.2012.07.015, 2012.

Argerich, A., Haggerty, R., Johnson, S. L., Wondzell, S. M., Dosch, N., Corson-Rikert, H., Ashkenas, L. R., Pennington, R., and Thomas, C. K.: Comprehensive multiyear carbon budget of a temperate headwater stream, J. Geophys. Res.-Biogeo., 121, 1306-1315, https://doi.org/10.1002/2015jg003050, 2016.

Battin, T. J., Kaplan, L. A., Findlay, S., Hopkinson, C. S., Marti, E., Packman, A. I., Newbold, J. D., and Sabater, F.: Biophysical controls on organic carbon fluxes in fluvial networks, Nat. Geosci., 1, 95-100, https://doi.org/10.1038/ngeo101, 2008.

Beel, C. R., Lamoureux, S. F., and Orwin, J. F.: Fluvial response to a period of hydrometeorological change and landscape disturbance in the Canadian high Arctic, Geophys. Res. Lett., 45, 1044610455, https://doi.org/10.1029/2018g1079660, 2018.

Benda, L., Hassan, M. A., Church, M., and May, C. L.: Geomorphology of steepland headwaters: the transition from hillslopes to channels, J. Am. Water Resour. As., 41, 835-851, https://doi.org/10.1111/j.1752-1688.2005.tb03773.x, 2005.

Bianchi, T. S. and Canuel, E. A.: Chemical biomarkers in aquatic ecosystems, Princeton University Press, 392 pp., ISBN 9780691134147, 2011.

Biggs, J., von Fumetti, S., and Kelly-Quinn, M.: The importance of small waterbodies for biodiversity and ecosystem services: implications for policy makers, Hydrobiologia, 793, 3-39, https://doi.org/10.1007/s10750-016-3007-0, 2017.

Bissell, H. J. and Chilingar, G. V.: Classification of sedimentary carbonate rocks, Develop. Sedimentol., 9, 87-168, 1967.

Bouillon, S., Yambélé, A., Spencer, R. G. M., Gillikin, D. P., Hernes, P. J., Six, J., Merckx, R., and Borges, A. V.: Organic matter sources, fluxes and greenhouse gas exchange in the Oubangui River (Congo River basin), Biogeosciences, 9, 2045-2062, https://doi.org/10.5194/bg-9-2045-2012, 2012.

Bröder, L., Davydova, A., Davydov, S., Zimov, N., Haghipour, N., Eglinton, T. I., and Vonk, J. E.: Particulate organic matter dynamics in a permafrost headwater stream and the Kolyma River mainstem, J. Geophys. Res.-Biogeo., 125, 16, https://doi.org/10.1029/2019jg005511, 2020.

Cai, W.-J., Guo, X., Chen, C.-T. A., Dai, M., Zhang, L., Zhai, W., Lohrenz, S. E., Yin, K., Harrison, P. J., and Wang, Y.: A comparative overview of weathering intensity and $\mathrm{HCO}_{3}^{-}$flux in the world's major rivers with emphasis on the Changjiang, Huanghe, Zhujiang (Pearl) and Mississippi Rivers, Cont. Shelf Res., 28, 1538-1549, https://doi.org/10.1016/j.csr.2007.10.014, 2008.

Caillon, F. and Schelker, J.: Dynamic transfer of soil bacteria and dissolved organic carbon into small streams during hydrological events, Aquat. Sci., 82, 11, https://doi.org/10.1007/s00027-0200714-4, 2020.

Carey, S. K. and Quinton, W. L.: Evaluating snowmelt runoff generation in a discontinuous permafrost catchment using stable isotope, hydrochemical and hydrometric data, Nord. Hydrol., 35, 309-324, 2004.

Chang, J., Ye, R. Z., and Wang, G. X.: Review: Progress in permafrost hydrogeology in China, Hydrogeol. J., 26, 1387-1399, https://doi.org/10.1007/s10040-018-1802-6, 2018.

Chen, H., Zhu, Q. A., Peng, C. H., Wu, N., Wang, Y. F., Fang, X. Q., Gao, Y. H., Zhu, D., Yang, G., Tian, J. Q., Kang, X. M., Piao, S. L., Ouyang, H., Xiang, W. H., Luo, Z. B., Jiang, H., Song, X. Z., Zhang, Y., Yu, G. R., Zhao, X. Q., Gong, P., Yao, T. D., and Wu, J. H.: The impacts of climate change and human activities on biogeochemical cycles on the Qinghai-Tibetan Plateau, Glob. Change Biol., 19, 2940-2955, https://doi.org/10.1111/gcb.12277, 2013.

Cheng, S., Cao, S., Cao, G., Han, J., Han, G., and Wu, F.: Comparisons of supervised classification methods for land cover based on high spatial resolution remote sensing images in Shaliu River basin of Qinghai Lake, Bull. Soil Water Conserv., 38, 261-268, 2018.

Chiasson-Poirier, G., Franssen, J., Lafreniere, M. J., Fortier, D., and Lamoureux, S. F.: Seasona evolution of active layer thaw depth and hillslope-stream connectivity in a permafrost watershed, Water Resour. Res., 56, 18, https://doi.org/10.1029/2019wr025828, 2020.

Dai, G. H., Zhu, E. X., Liu, Z. G., Wang, Y. Y., Zhu, S. S., Wang, S. M., Ma, T., Jia, J., Wang, X., Hou, S. J., Fu, P. Q., Peterse, F., and Feng, X. J.: Compositional characteristics of fluvial particulate organic matter exported from the world's largest alpine wetland, J. Geophys. Res.-Biogeo., 124, 27092727, https://doi.org/10.1029/2019jg005231, 2019.

Dornblaser, M. M. and Striegl, R. G.: Switching predominance of organic versus inorganic carbon exports from an intermediatesize subarctic watershed, Geophys. Res. Lett., 42, 386-394, https://doi.org/10.1002/2014g1062349, 2015.

Downing, J. A., Cole, J. J., Duarte, C. M., Middelburg, J. J., Melack, J. M., Prairie, Y. T., Kortelainen, P., Striegl, R. G., McDowell, W. H., and Tranvik, L. J.: Global abundance and size distribution of streams and rivers, Inland Waters, 2, 229-236, https://doi.org/10.5268/iw-2.4.502, 2012.

Flury, S. and Ulseth, A. J.: Exploring the sources of unexpected high methane concentrations and fluxes from alpine headwater streams, Geophys. Res. Lett., 46, 6614-6625, https://doi.org/10.1029/2019gl082428, 2019.

French, D. W., Schindler, D. E., Brennan, S. R., and Whited, D.: Headwater catchments govern biogeochemistry in America's 
largest free-flowing river network, J. Geophys. Res.-Biogeo., 125, 20, https://doi.org/10.1029/2020jg005851, 2020.

Gao, T. G., Kang, S. C., Chen, R. S., Zhang, T. G., Zhang, T. J., Han, C. T., Tripathee, L., Sillanpaa, M., and Zhang, Y. L.: Riverine dissolved organic carbon and its optical properties in a permafrost region of the Upper Heihe River basin in the Northern Tibetan Plateau, Sci. Total Environ., 686, 370-381, https://doi.org/10.1016/j.scitotenv.2019.05.478, 2019.

Giesler, R., Lyon, S. W., Mörth, C.-M., Karlsson, J., Karlsson, E. M., Jantze, E. J., Destouni, G., and Humborg, C.: Catchmentscale dissolved carbon concentrations and export estimates across six subarctic streams in northern Sweden, Biogeosciences, 11, 525-537, https://doi.org/10.5194/bg-11-525-2014, 2014.

Gomi, T., Sidle, R. C., and Richardson, J. S.: Understanding processes and downstream linkages of headwater systems, Bioscience, 52, 905-916, https://doi.org/10.1641/00063568(2002)052[0905:Upadlo]2.0.Co;2, 2002.

Guo, L. D., Cai, Y. H., Belzile, C., and Macdonald, R. W.: Sources and export fluxes of inorganic and organic carbon and nutrient species from the seasonally ice-covered Yukon River, Biogeochemistry, 107, 187-206, https://doi.org/10.1007/s10533-0109545-z, 2012.

Harrison, J. A., Seitzinger, S. P., Bouwman, A. F., Caraco, N. F., Beusen, A. H. W., and Vorosmarty, C. J.: Dissolved inorganic phosphorus export to the coastal zone: Results from a spatially explicit, global model, Global Biogeochem. Cy., 19, 17, https://doi.org/10.1029/2004gb002357, 2005.

Hedges, J. I. and Ertel, J. R.: Characterization of lignin by gas capillary chromatography of cupric oxidation-products, Anal. Chem., 54, 174-178, https://doi.org/10.1021/ac00239a007, 1982.

Hedges, J. I. and Mann, D. C.: Lignin geochemistry of marinesediments from the southern Washington Coast, Geochim. Cosmochim. Ac., 43, 1809-1818, https://doi.org/10.1016/00167037(79)90029-2, 1979.

Hedges, J. I., Blanchette, R. A., Weliky, K., and Devol, A. H.: Effects of fungal degradation on the $\mathrm{CuO}$ oxidation products of lignin: A controlled laboratory study, Geochim. Cosmochim. Ac., 52, 2717-2726, https://doi.org/10.1016/00167037(88)90040-3, 1988.

Hernes, P. J., Robinson, A. C., and Aufdenkampe, A. K.: Fractionation of lignin during leaching and sorption and implications for organic matter "freshness", Geophys. Res. Lett., 34, L17401, https://doi.org/10.1029/2007gl031017, 2007.

Huang, T.-H., Fu, Y.-H., Pan, P.-Y., and Chen, C.-T. A.: Fluvial carbon fluxes in tropical rivers, Curr. Opin. Environ. Sustain., 4, 162-169, https://doi.org/10.1016/j.cosust.2012.02.004, 2012.

Immerzeel, W. W., van Beek, L. P. H., and Bierkens, M. F. P.: Climate change will affect the Asian Water Towers, Science, 328, 1382-1385, https://doi.org/10.1126/science.1183188, 2010.

IUSS working group: World Reference Base for Soil Resources 2014, update 2015 International soil classification system for naming soils and creating legends for soil maps, World Soil Resources Reports, NO. 106, FAO, Rome, 2015.

Jia, J., Cao, Z. J., Liu, C. Z., Zhang, Z. H., Lin, L., Wang, Y. Y., Haghipour, N., Wacker, L., Bao, H. Y., Dittmar, T., Simpson, M. J., Yang, H., Crowther, T. W., Eglinton, T. I., He, J. S., and Feng, X. J.: Climate warming alters subsoil but not topsoil carbon dynamics in alpine grassland, Glob. Change Biol., 25, 4383-4393, https://doi.org/10.1111/gcb.14823, 2019.
Jin, Z. D., Yu, J. M., Wang, S. M., Zhang, F., Shi, Y. W., and You, C. F.: Constraints on water chemistry by chemical weathering in the Lake Qinghai catchment, northeastern Tibetan Plateau (China): clues from $\mathrm{Sr}$ and its isotopic geochemistry, Hydrogeol. J., 17, 2037-2048, https://doi.org/10.1007/s10040-009-0480-9, 2009.

Johnson, M. S., Lehmann, J., Couto, E. G., Novaes, J. P., and Riha, S. J.: DOC and DIC in flowpaths of Amazonian headwater catchments with hydrologically contrasting soils, Biogeochemistry, 81, 45-57, https://doi.org/10.1007/s10533-006-9029-3, 2006.

Lambert, T., Teodoru, C. R., Nyoni, F. C., Bouillon, S., Darchambeau, F., Massicotte, P., and Borges, A. V.: Alongstream transport and transformation of dissolved organic matter in a large tropical river, Biogeosciences, 13, 2727-2741, https://doi.org/10.5194/bg-13-2727-2016, 2016.

Li, C., Li, X., Yang, T., and Li, Y.: Structure and Species Diversity of Meadow Community along the Shaliu River in the Qinghai Lake Basin, Arid Zone Research, 30, 1028-1035, 2013.

Liu, S. D., Butman, D. E., and Raymond, P. A.: Evaluating $\mathrm{CO}_{2}$ calculation error from organic alkalinity and $\mathrm{pH}$ measurement error in low ionic strength freshwaters, Limnol. Oceanogr.-Meth., 18, 606-622, https://doi.org/10.1002/lom3.10388, 2020.

Liu, T., Wang, L., Feng, X., Zhang, J., Ma, T., Wang, X., and Liu, Z.: Comparing soil carbon loss through respiration and leaching under extreme precipitation events in arid and semiarid grasslands, Biogeosciences, 15, 1627-1641, https://doi.org/10.5194/bg-151627-2018, 2018.

Liu, T., Wang, X., Zhu, E. X., Liu, Z. G., Zhang, X. Y., Guo, J. J., Liu, X. Q., He, C., Hou, S. J., Fu, P. Q., Shi, Q., and Feng, X. J.: Evolution of the dissolved organic matter composition along the Upper Mekong (Lancang) River, ACS Earth Space Chem., 5, 319-330, https://doi.org/10.1021/acsearthspacechem.0c00292, 2021.

Louchouarn, P., Amon, R. M. W., Duan, S. W., Pondell, C., Seward, S. M., and White, N.: Analysis of lignin-derived phenols in standard reference materials and ocean dissolved organic matter by gas chromatography/tandem mass spectrometry, Mar. Chem., 118, 85-97, https://doi.org/10.1016/j.marchem.2009.11.003, 2010.

Mann, P. J., Eglinton, T. I., McIntyre, C. P., Zimov, N., Davydova, A., Vonk, J. E., Holmes, R. M., and Spencer, R. G. M.: Utilization of ancient permafrost carbon in headwaters of Arctic fluvial networks, Nat. Commun., 6, 7, https://doi.org/10.1038/ncomms8856, 2015.

Mann, P. J., Spencer, R. G. M., Hernes, P. J., Six, J., Aiken, G. R., Tank, S. E., McClelland, J. W., Butler, K. D., Dyda, R. Y., and Holmes, R. M.: Pan-Arctic Trends in Terrestrial Dissolved Organic Matter from Optical Measurements, Front. Earth Sci., 4, 18, https://doi.org/10.3389/feart.2016.00025, 2016.

Opsahl, S. and Benner, R.: Early diagenesis of vascular planttissues-lignin and cutin decomposition and biogeochemical implications, Geochim. Cosmochim. Ac., 59, 4889-4904, https://doi.org/10.1016/0016-7037(95)00348-7, 1995.

Öquist, M. G., Bishop, K., Grelle, A., Klemedtsson, L., Kohler, S. J., Laudon, H., Lindroth, A., Lofvenius, M. O., Wallin, M. B., and Nilsson, M. B.: The full annual carbon balance of boreal forests is highly sensitive to precipitation, Environ. Sci. Tech. Let., 1, 315-319, https://doi.org/10.1021/ez500169j, 2014.

Otto, A. and Simpson, M. J.: Evaluation of $\mathrm{CuO}$ oxidation parameters for determining the source and stage of 
lignin degradation in soil, Biogeochemistry, 80, 121-142, https://doi.org/10.1007/s10533-006-9014-x, 2006.

Pereira, R., Bovolo, C. I., Spencer, R. G. M., Hernes, P. J., Tipping, E., Vieth-Hillebrand, A., Pedentchouk, N., Chappell, N. A., Parkin, G., and Wagner, T.: Mobilization of optically invisible dissolved organic matter in response to rainstorm events in a tropical forest headwater river, Geophys. Res. Lett., 41, 12021208, https://doi.org/10.1002/2013gl058658, 2014.

Prokushkin, A. S., Pokrovsky, O. S., Shirokova, L. S., Korets, M. A., Viers, J., Prokushkin, S. G., Amon, R. M. W., Guggenberger, G., and McDowell, W. H.: Sources and the flux pattern of dissolved carbon in rivers of the Yenisey basin draining the Central Siberian Plateau, Environ. Res. Lett., 6, 14, https://doi.org/10.1088/1748-9326/6/4/045212, 2011.

Qiu, J.: The third pole, Nature, 454, 393-396, https://doi.org/10.1038/454393a, 2008.

Qu, B., Sillanpaa, M., Li, C. L., Kang, S. C., Stubbins, A., Yan, F. P., Aho, K. S., Zhou, F., and Raymond, P. A.: Aged dissolved organic carbon exported from rivers of the Tibetan Plateau, Plos One, 12, 11, https://doi.org/10.1371/journal.pone.0178166, 2017.

Ran, L. S., Lu, X. X., Sun, H. G., Han, J. T., Li, R. H., and Zhang, J. M.: Spatial and seasonal variability of organic carbon transport in the Yellow River, China, J. Hydrol., 498, 76-88, https://doi.org/10.1016/j.jhydrol.2013.06.018, 2013.

Richardson, J. S., Naiman, R. J., Swanson, F. J., and Hibbs, D. E.: Riparian communities associated with Pacific Northwest headwater streams: Assemblages, processes, and uniqueness, J. Am. Water Resour. As., 41, 935-947, https://doi.org/10.1111/j.17521688.2005.tb03778.x, 2005.

Rivenbark, B. L. and Jackson, C. R.: Average discharge, perennial flow initiation, and channel initiation - Small Southern Appalachian basins, J. Am. Water Resour. As., 40, 639-646, https://doi.org/10.1111/j.1752-1688.2004.tb04449.x, 2004.

Runkel, R. L., Crawford, C. G., and Cohn, T. A.: Load estimator (LOADEST): A FORTRAN program for estimating constituent loads in streams and rivers. In U.S. Geological Survey Techniques and Methods Book (Chap. A5, Vol. 4, 69 pp.), Denver, CO: US Geological Survey, https://doi.org/10.3133/tm4A5, 2004.

Seitzinger, S. P., Harrison, J. A., Dumont, E., Beusen, A. H. W., and Bouwman, A. F.: Sources and delivery of carbon, nitrogen, and phosphorus to the coastal zone: An overview of Global Nutrient Export from Watersheds (NEWS) models and their application, Global Biogeochem. Cy., 19, 11, https://doi.org/10.1029/2005gb002606, 2005.

Song, C. L., Wang, G., Mao, T. X., Chen, X. P., Huang, K. W., Sun, X. Y., and Hu, Z. Y.: Importance of active layer freeze-thaw cycles on the riverine dissolved carbon export on the Qinghai-Tibet Plateau permafrost region, PeerJ, 7, 25, https://doi.org/10.7717/peerj.7146, 2019.

Song, C. L., Wang, G. X., Haghipour, N., and Raymond, P. A.: Warming and monsoonal climate lead to large export of millennial-aged carbon from permafrost catchments of the Qinghai-Tibet Plateau, Environ. Res. Lett., 15, 13, https://doi.org/10.1088/1748-9326/ab83ac, 2020.

Spencer, R. G. M., Aiken, G. R., Wickland, K. P., Striegl, R. G., and Hernes, P. J.: Seasonal and spatial variability in dissolved organic matter quantity and composition from the
Yukon River basin, Alaska, Global Biogeochem. Cy., 22, 13, https://doi.org/10.1029/2008gb003231, 2008.

Spencer, R. G. M., Aiken, G. R., Dyda, R. Y., Butler, K. D., Bergamaschi, B. A., and Hernes, P. J.: Comparison of $\mathrm{XAD}$ with other dissolved lignin isolation techniques and a compilation of analytical improvements for the analysis of lignin in aquatic settings, Org. Geochem., 41, 445-453, https://doi.org/10.1016/j.orggeochem.2010.02.004, 2010a.

Spencer, R. G. M., Hernes, P. J., Ruf, R., Baker, A., Dyda, R. Y., Stubbins, A., and Six, J.: Temporal controls on dissolved organic matter and lignin biogeochemistry in a pristine tropical river, Democratic Republic of Congo, J. Geophys. Res.-Biogeo., 115, G03013, https://doi.org/10.1029/2009jg001180, 2010 b.

Striegl, R. G., Dornblaser, M. M., Aiken, G. R., Wickland, K. P., and Raymond, P. A.: Carbon export and cycling by the Yukon, Tanana, and Porcupine rivers, Alaska, 2001-2005, Water Resour. Res., 43, 9, https://doi.org/10.1029/2006wr005201, 2007.

Svec, J. R., Kolka, R. K., and Stringer, J. W.: Defining perennial, intermittent, and ephemeral channels in Eastern Kentucky: Application to forestry best management practices, Forest Ecol. Manag., 214, 170-182, https://doi.org/10.1016/j.foreco.2005.04.008, 2005.

Tank, S. E., Raymond, P. A., Striegl, R. G., McClelland, J. W., Holmes, R. M., Fiske, G. J., and Peterson, B. J.: A land-to-ocean perspective on the magnitude, source and implication of DIC flux from major Arctic rivers to the Arctic Ocean, Global Biogeochem. Cy., 26, 15, https://doi.org/10.1029/2011gb004192, 2012.

Tarnocai, C., Canadell, J. G., Schuur, E. A. G., Kuhry, P., Mazhitova, G., and Zimov, S.: Soil organic carbon pools in the northern circumpolar permafrost region, Global Biogeochem. Cy., 23, 11, https://doi.org/10.1029/2008gb003327, 2009.

Tetzlaff, D., Buttle, J., Carey, S. K., McGuire, K., Laudon, H., and Soulsby, C.: Tracer-based assessment of flow paths, storage and runoff generation in northern catchments: a review, Hydrol. Process., 29, 3475-3490, https://doi.org/10.1002/hyp.10412, 2015.

Vonk, J. E., Tank, S. E., Bowden, W. B., Laurion, I., Vincent, W. F., Alekseychik, P., Amyot, M., Billet, M. F., Canário, J., Cory, R. M., Deshpande, B. N., Helbig, M., Jammet, M., Karlsson, J., Larouche, J., MacMillan, G., Rautio, M., Walter Anthony, K. M., and Wickland, K. P.: Reviews and syntheses: Effects of permafrost thaw on Arctic aquatic ecosystems, Biogeosciences, 12, 7129-7167, https://doi.org/10.5194/bg-12-7129-2015, 2015.

Walvoord, M. A. and Kurylyk, B. L.: Hydrologic impacts of thawing permafrost: A review, Vadose Zone J., 15, 20, https://doi.org/10.2136/vzj2016.01.0010, 2016.

Walvoord, M. A. and Striegl, R. G.: Increased groundwater to stream discharge from permafrost thawing in the Yukon River basin: Potential impacts on lateral export of carbon and nitrogen, Geophys. Res. Lett., 34, 6, https://doi.org/10.1029/2007gl030216, 2007.

Wang, G. X., Mao, T. X., Chang, J., Song, C. L., and Huang, K. W.: Processes of runoff generation operating during the spring and autumn seasons in a permafrost catchment on semi-arid plateaus, J. Hydrol., 550, 307-317, https://doi.org/10.1016/j.jhydrol.2017.05.020, 2017.

Wang, X., Zhao, X. L., Zhang, Z. X., Yi, L., Zuo, L. J., Wen, Q. K., Liu, F., Xu, J. Y., Hu, S. G., and Liu, B.: Assessment of soil erosion change and its relationships with land use/cover change 
in China from the end of the 1980s to 2010, Catena, 137, 256268, https://doi.org/10.1016/j.catena.2015.10.004, 2016.

Wang, Y., Spencer, R. G. M., Podgorski, D. C., Kellerman, A. M., Rashid, H., Zito, P., Xiao, W., Wei, D., Yang, Y., and Xu, Y.: Spatiotemporal transformation of dissolved organic matter along an alpine stream flow path on the Qinghai-Tibet Plateau: importance of source and permafrost degradation, Biogeosciences, 15, 6637-6648, https://doi.org/10.5194/bg-15-6637-2018, 2018.

Wiegner, T. N., Seitzinger, S. P., Glibert, P. M., and Bronk, D. A.: Bioavailability of dissolved organic nitrogen and carbon from nine rivers in the eastern United States, Aquat. Microb. Ecol., 43, 277-287, https://doi.org/10.3354/ame043277, 2006.

Wu, H. W., Li, X. Y., Li, J., Jiang, Z. Y., Chen, H. Y., Ma, Y. J., and Huang, Y. M.: Differential soil moisture pulse uptake by coexisting plants in an alpine Achnatherum splendens grassland community, Environ. Earth Sci., 75, 13, https://doi.org/10.1007/s12665-016-5694-2, 2016.

Xiao, J., Jin, Z. D., and Zhang, F.: Geochemical and isotopic characteristics of shallow groundwater within the Lake Qinghai catchment, NE Tibetan Plateau, Quatern. Int., 313, 62-73, https://doi.org/10.1016/j.quaint.2013.05.033, 2013.

Yang, Y. H., Fang, J. Y., Tang, Y. H., Ji, C. J., Zheng, C. Y., He, J. S., and Zhu, B. A.: Storage, patterns and controls of soil organic carbon in the Tibetan grasslands, Glob. Change Biol., 14, 15921599, https://doi.org/10.1111/j.1365-2486.2008.01591.x, 2008.

Yao, T. D., Masson-Delmotte, V., Gao, J., Yu, W. S., Yang, X. X., Risi, C., Sturm, C., Werner, M., Zhao, H. B., He, Y., Ren, W., Tian, L. D., Shi, C. M., and Hou, S. G.: A review of climatic controls on delta O-18 in precipitation over the Tibetan Plateau: observations and simulations, Rev. Geophys., 51, 24, https://doi.org/10.1002/rog.20023, 2013.
Zeng, S. B., Liu, Z. H., and Kaufmann, G.: Sensitivity of the global carbonate weathering carbon-sink flux to climate and land-use changes, Nat. Commun., 10, 10, https://doi.org/10.1038/s41467019-13772-4, 2019.

Zhang, F., Jin, Z. D., Li, F. C., Yu, J. M., and Xiao, J.: Controls on seasonal variations of silicate weathering and $\mathrm{CO}_{2}$ consumption in, two river catchments on the NE Tibetan Plateau, J. Asian Earth Sci., 62, 547-560, https://doi.org/10.1016/j.jseaes.2012.11.004, 2013.

Zolkos, S., Tank, S. E., and Kokelj, S. V.: Mineral Weathering and the Permafrost Carbon-Climate Feedback, Geophys. Res. Lett., 45, 9623-9632, https://doi.org/10.1029/2018g1078748, 2018.

Zolkos, S., Krabbenhoft, D. P., Suslova, A., Tank, S. E., McClelland, J. W., Spencer, R. G. M., Shiklomanov, A., Zhulidov, A. V., Gurtovaya, T., Zimov, N., Zimov, S., Mutter, E. A., Kutny, L., Amos, E., and Holmes, R. M.: Mercury Export from Arctic Great Rivers, Environ. Sci. Technol., 54, 4140-4148, https://doi.org/10.1021/acs.est.9b07145, 2020.

Zou, D., Zhao, L., Sheng, Y., Chen, J., Hu, G., Wu, T., Wu, J., Xie, C., Wu, X., Pang, Q., Wang, W., Du, E., Li, W., Liu, G., Li, J., Qin, Y., Qiao, Y., Wang, Z., Shi, J., and Cheng, G.: A new map of permafrost distribution on the Tibetan Plateau, The Cryosphere, 11, 2527-2542, https://doi.org/10.5194/tc-11-2527-2017, 2017. 